\title{
Development of Flapping Wing Hydroelectric Power Generator
}

\section{正 阿比留 久徳（福工大） 吉武 朗（九大）}

Hisanori ABIRU, Fukuoka Institute of Technology, 3-30-1 Wajiro-Higashi, Higashi-ku, Fukuoka Akira YOSHITAKE, Kyushu University,

Key Words: Natural energy, Distributed generation, Hydroelectric power generation, Flutter

\section{1.}

石油代替エネルギーとしてさまざまな自然エネルギー の利用が推進されている. 我が国には，比較的流速の速い中 小河川や灌溉用水路が多く, その潜在的発電能力は数百万 $\mathrm{kW}$ になると推定されている.これらの水流を利用するマイ クロ水力は, 太陽光や風力とならんで新エネルギーに取り上 げられており, 今後分散型電源としての展開が期待される. 河川の流れからエネルギーを取り出す方法としては従来か ら種々の水車が用いられている.これらは，1-2m の落差, すなわち $4-6 \mathrm{~m} / \mathrm{s}$ の流速を必要としている. このため, 落差 のない水路では一般的に初期費用のかさむ落差をつけるた めの対策が必要となり，このことがマイクロ水力発電の普及 を阻害している要因の一つになっている.

最近ではダリウス型水車やスパイラルタービンブレード の利用など, より低落差, 低流速で高効率化を図る提案や改 良 (1)などが行われている.

一方, 風力発電を対象にして, 航空機の翼や橋梁等で破壊 的な振動を引き起すフラッタ現象を利用する研究が古くか らあり ${ }^{(2)}$, 最近では風車に匹敵する高効率の発電システムが 磯貝らにより提案され理論的検討が行われている ${ }^{(3)}$.

この発電システムは,たわみ方向に弾性的に支持された翼 に, モーターによってある与えられた振動数と振幅のピッチ ング振動を強制的に与えるシステムで, ピッチング振動によ

つて励起されるたわみ振動を利用して発電を行う.

先の研究で, 小型の原理検証用の装置を用いて発電量, 発 電効率を実験的に調べ, このシステムが水力発電装置として も実用可能であることを示した ${ }^{(6)}$.

本研究では, このシステムの実用化に向けより大型化した 200W クラスの装置を用いて，室内の回流水槽において，ま た一部は実際の農業用水路において発電性能の検証を行っ た.

\section{2. 实䁌淕昷}

本研究で製作した装置の概要を図 1 に示す. 翼は片持ち 支持にして, 水中には翼のみを浸す構造とした. 翼とそれに ピッチング振動を与えるモーター部分は4本のロッドで振り 子にして支持し, 復元力を与えるばねの機能を兼ねた. また, メカニカルスナッバによってスウェイ振動に対する所要の 等価質量を得, 磁気ダンパによって発電に相当する負荷を与 えた。

2 ・1 装固設計 設計に用いた手法は先の研究と同様で ある. 概要を以下に示す。

図 1 に示す系を支配する運動方程式は次式で与えられる.

$$
M_{s} \frac{d^{2} H}{d t^{2}}+\omega_{s}^{2} M_{s}(1+i g) H=L+M_{p} x_{\alpha} \frac{d^{2} \alpha}{d t^{2}}
$$

本装置では，ピッチング振動を与えるモーターの消費動力 低減のため, $x_{\alpha}=0$, すなわちピッチ軸を翼の重心に一致させ て式（1）の右辺第 2 項を消去した.

揚力としては, 理論解が与えられている 2 次元線形ポテン シャル理論による非定常流体力 (4) を用いた。

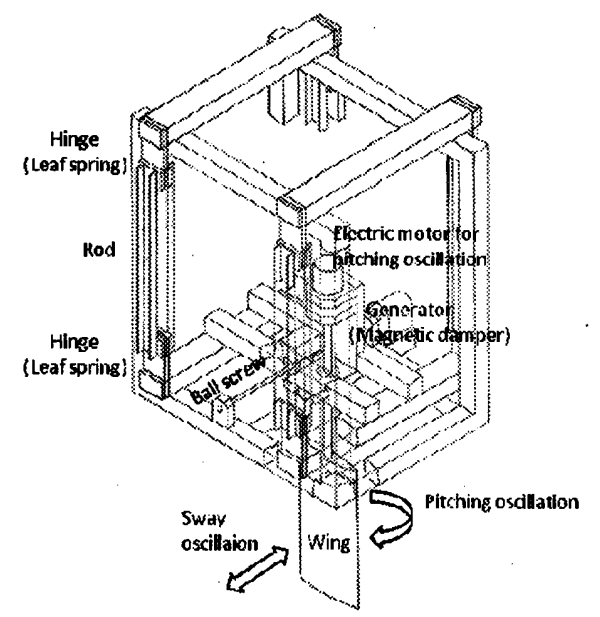

Fig. 1 Schematic view of experimental apparatus

構造減衰係数 $g$ には, 装置の構造減衰および発電に相当する 負荷を与える磁気ダンパの等価構造減衰を含む.

式（1）の無次元表示から得られる 5 つの無次元パラメー 夕 $k, g, \omega_{s} / \omega, \mu$ と $a$ を仮定して式（1）を解き, 翼のた わみ振幅を求め, 構造減衰で消費される発電に相当するエネ ルギーの時間平均を計算する。

装置の設計では，まず $b, l, U$ と $\alpha_{0}$ を設定するが，上記 5 つの無次元パラメータは. 実現性の制約を考虑したうえで発 電効率ができるだけ大きくなるように決定した. 発電効率は 次式による ${ }^{(3)}$.

$$
\eta_{p}=W /\left[\frac{16}{27}\left(\frac{1}{2} \rho S U^{3}\right)\right]
$$

ここで, 式 (2) 中の 16/27 はベッツの限界 (5) と呼ばれる 係数で, 理論上得られる最大効率を示す.

$2 \cdot 2$ フラッタ発角装固使用する翼は半翼弦長 $b=200 \mathrm{~mm}$, 翼幅 $l=600 \mathrm{~mm}$ の NACA0015 翼型で, 設計条件と 代表性能を表 1 に示す. 表中の発電量 W は先の研究 ${ }^{(6)}$ で得 られた翼の 3 次元効果の影響を反映した結果である. 図 2 に 製作した装置を示す.

\section{3. 实㰸}

$3 \cdot 1$ 室内実免 農業用水路での実験に先立ち回流水槽 での室内実験を行った. 水槽は九州大学伊都キャンパスに設 置されている高速回流水槽である. 水路は垂直回流型で, 測 
Table 1 Specification of experimental apparatus

\begin{tabular}{|c|c|c|c|}
\hline $\begin{array}{ll}b & {[\mathrm{~m}]}\end{array}$ & 0.20 & $g$ & 3.00 \\
\hline$l \quad[\mathrm{~m}]$ & 0.60 & $\omega_{\mathrm{s}} / \omega$ & 0.70 \\
\hline$U \quad[\mathrm{~m} / \mathrm{s}]$ & 2.00 & $\mu$ & 6.00 \\
\hline$\alpha_{0}[\mathrm{deg}]$ & 50.00 & $a$ & 0.00 \\
\hline$\omega[\mathrm{rad} / \mathrm{s}]$ & 2.13 & $W \quad[\mathrm{~W}]$ & 218 \\
\hline$k$ & 0.21 & $\eta_{\mathrm{p}}$ & 0.46 \\
\hline
\end{tabular}

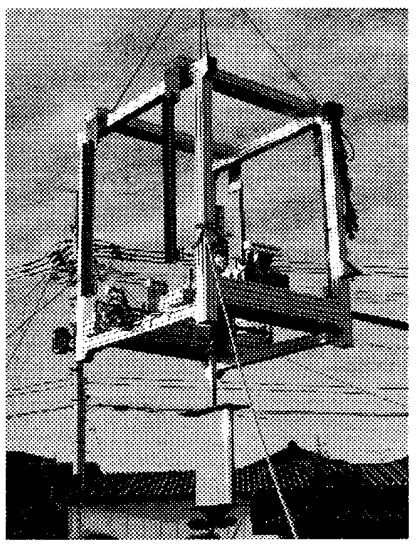

Fig.2 Experimental apparatus

定部壮，水路幅 $2000 \mathrm{~mm}$ ，水深 $1000 \mathrm{~mm}$ ，長さ $4000 \mathrm{~mm}$ であ り，流速は $0.3 \mathrm{~m} / \mathrm{s} \sim 3.3 \mathrm{~m} / \mathrm{s}$ の間で設定できる，㥶験装置を設 置した.状況を図 3 に示す.

\section{$3 \cdot 2$ 屋外実跧 実験を行った農業用水路はうきは市に} ある大:石長野水道で, 実験地点の状況を図 4, 表 3 に示寸.

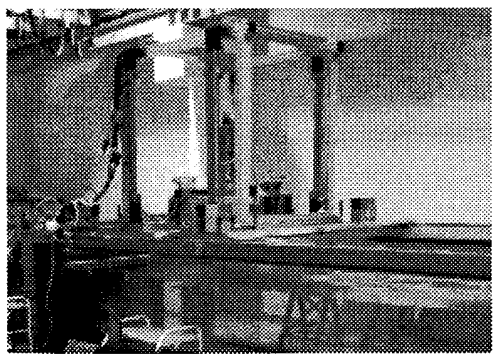

Fig. 3 Circulating water channel

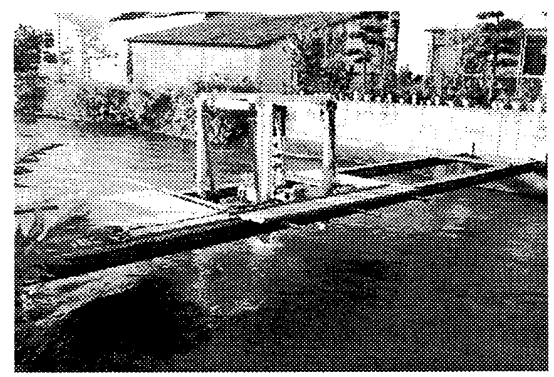

Fig. 4 Irrigation canal

Table 3 Condition of irrigation canal

\begin{tabular}{|c|c|}
\hline Width $(\mathrm{m})$ & 10 \\
\hline Depth $(\mathrm{m})$ & 0.8 \\
\hline Flow velocity $(\mathrm{m} / \mathrm{s})$ & 2.05 \\
\hline
\end{tabular}

3 -3 実跧結果および考察 ピッチ振動振幅 $\alpha_{0}=50 \mathrm{deg}$ の場合の室内実験での流速と発電量の関係を図 5 に, $\alpha_{0}=30 \mathrm{deg}$ の場合の室内および屋外での結果を図 6 に示す.
両結果とも流速の増加と伴に発電量は大きく増加し、ほぼ設 計値通りの発電量が得られた. 室内実験では $\alpha_{0}=50 \mathrm{deg}$ の場 合, 流速 $U=2 \mathrm{~m} / \mathrm{s}$ の設計条件で発電量 $250 \mathrm{~W}$ が得られた. こ の值は翼の 3 次元効果の影響を無視した 2 次元線形ポテンシ ヤル理論にもとづく理論値の $60 \%$ の発電量に相当する.

実際の農業用水路では，装置のトラブルで $\alpha_{0}=30 \mathrm{deg}$ のみ の結果であるが，発電量は設計值および室内実験の結果と対 応しており，実際の水路の流れ状況の影響をほとんど受けな いことが確認できた。

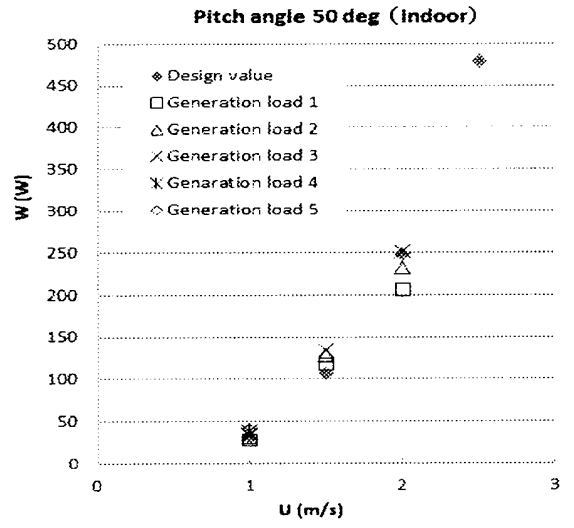

Fig.5 Power versus flow velocity (Indoor test)

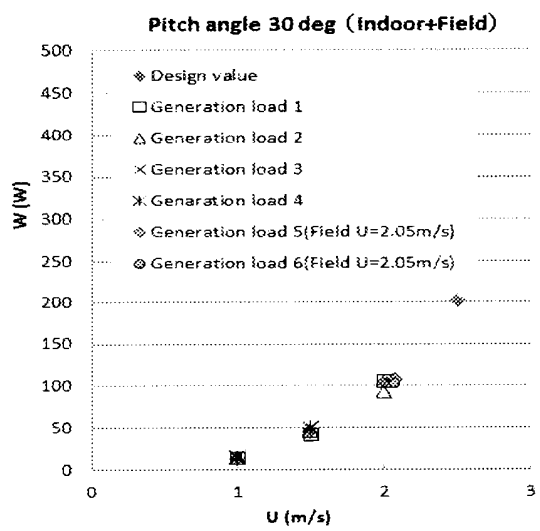

Fig.6 Power versus flow velocity (Indoor \& Field test)

\section{文获}

(1) Shiono,M., Suzuki,K. and Kiho,S., Comparison of Water Turbine Characteristics using Different Blades in Darrieus Water Turbines used for Tidal Current Generations, IEEJ Transactions on Power and Energy, Vol.123-B, No.1 (2003), pp.76-82.

(2) McKinney,W. and Delaurier,J., The Wingmill : An Oscillating-Wing Windmill, Journal of Energy, Vol.5, No.2 (1981), pp.109-115.

(3) Shimizu,E., Isogai,K. and Obayashi,S., Multi Objective Design Study of a Flapping Wing Power Generator, Transaction of the ASME, Journal of Fluids Engineering, Vol.130, (2008).

(4) Theodorsen, T., General Theory of Aerodynamic Instability and Mechanism of Flutter, NACA Report 496 (1935).

(5) Johnson,G.L., Wind Energy System, (1985), p.127, Prentice Hall Inc., Englewood Cliffs, NJ.

(6) Abiru,H., Yoshitake,A. (2011), "Study on a Flapping Wing Hydroelectric Power Generation System", JEE, JSME, Vol.6 (1), 178-186. 